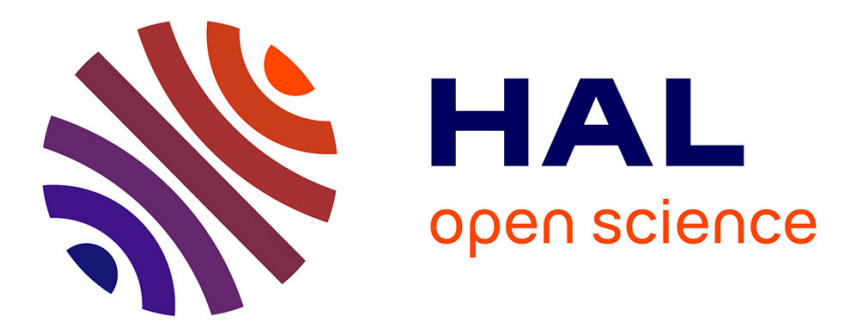

\title{
Societal responsibility of business and information systems
}

Hugues Poissonnier, Claudio Vitari, Raffi Duymedjian, Renaud Cornu-Emieux

\section{To cite this version:}

Hugues Poissonnier, Claudio Vitari, Raffi Duymedjian, Renaud Cornu-Emieux. Societal responsibility of business and information systems. International Conference on Information Systems, Technology and Management, 2011, Gurgaon, India. 10.1007/978-3-642-19423-8_12 . halshs-01924274

\section{HAL Id: halshs-01924274 \\ https://shs.hal.science/halshs-01924274}

Submitted on 17 Nov 2018

HAL is a multi-disciplinary open access archive for the deposit and dissemination of scientific research documents, whether they are published or not. The documents may come from teaching and research institutions in France or abroad, or from public or private research centers.
L'archive ouverte pluridisciplinaire HAL, est destinée au dépôt et à la diffusion de documents scientifiques de niveau recherche, publiés ou non, émanant des établissements d'enseignement et de recherche français ou étrangers, des laboratoires publics ou privés. 


\title{
Societal Responsibility of Business and Information Systems
}

\author{
Hugues Poissonnier ${ }^{1}$, Claudio Vitari ${ }^{1}$, Raffi Duymedjian ${ }^{1}$, and Renaud Cornu-Emieux ${ }^{2}$ \\ ${ }^{1}$ Grenoble Ecole De Management \\ ${ }^{2}$ Ecole de Management Des Systems D'Information \\ 12, rue Pierre Sémard - BP 127 - 38003 Grenoble Cedex 01 \\ hugues.poissonnier@grenoble-em.com, \\ renaud.cornu-emieux@emsi-grenoble.com
}

\begin{abstract}
In this chapter, we present the development of the (CSR) corporate social responsibility as a factor of development of the use of the IS. First, we examine in detail how companies can seek to optimize the (positive or negative) externalities associated with ICTs in their lifecycle. Then we insist on the fact that businesses appear increasingly forced to act in order to communicate. Finally, we discuss the potential offered by ICT and SID in terms of preserving the environment and social progress. The IS are then used in a resolutely proactive approach towards CSR.
\end{abstract}

Keywords: Societal responsibility, environment, social progress, development.

\section{Introduction}

Two types of representation of corporate social responsibility coexist today. The first one considers the social or environmental objectives as objectives "out of business". The second representation incorporates these objectives to the business strategy. A good news is linked to the fact that this second representation is more and more dominant.

Sustainable development and CSR are still largely in the public space incantatory speeches. It's even more real during a period of economic crisis.

This perception is growing not only in the citizen public space, but also in smaller spaces and theoretically under best "control", i.e. the Organization internal businesses. Information systems, strategic alignment and activity control fundamental instruments are thus first online when it comes to a company to maintain a strategic course integrating CSR and sustainable development concerns.

In this chapter, we propose a presentation of the roles of IS towards the implementation of CSR principles.

\section{Optimizing Externalities Associated with ICTs}

The first link that we discuss in this part, between SI and CSR is linked to the minimization of the negative impacts of the SI. We present, as a first step, externalities associated with various phases of the lifecycle of the SI, to highlight the most recent and future solutions. 


\subsection{The Lifecycle of ICTs and the Externalities Associated with Each Step}

ICTs generate new opportunities but also new risks in terms of sustainable development.

ICTs are quickly changing the world. However, alongside the dematerialization, globalization of the economy allowed among others by ICTs, stimulates the production of hardware products. Finally, ongoing innovation in ICT accelerates the renewal of skills, knowledge and existing products.

The life cycle theory con be used to explain the nature of trade flows or marketing and the developments in demand for a product. It can also explain the phenomena of emergence and renewal of ICTs. Identification of the different stages of the lifecycle of ICTs can serve as basis for the definition of externalities associated with each step. Three major steps can be taken: design, use and recycling. These externalities can be done on society and the environment, be positive (case should take advantage) or negative (it will be then to minimize).

\subsection{Towards a Better Use of the Capacity of ICT to Generate Positive Externalities}

The use of ICT can first generate positive externalities for society and the environment. Boudreau, Chen and Huber (2007) [1] attributed to ICT the capacity to contribute to:

- Reduction of costs of transport across the fleet vehicle routing and enterprise management systems.

- Limitation of travelling by air through collaboration and teleconferencing systems.

- Traceability of environmental information to the tower building products, components and services, through environmental information management systems.

- Increasing efficiency in the management of emissions and waste through environmental coaching systems

The provision of information to customers in order to increase transparency on the processes and the resources in place by the company through environmental reporting systems.

Next to these positive externalities, a number of efforts should be taken to reduce the negative externalities associated with ICTs in their lifecycle.

\subsection{To Reduce the Negative Externalities of ICT Solutions}

Organizations, like all social actors, contribute in their choice concerning ICT, to developments in the world.

ICTs can facilitate:

- The development of processors and disks that use less energy design

- The replacement of standard computers by energy efficient ones

- The use of the software to operate several software operating on the same server virtualization

- The reduction of energy consumption in the data center

- The reduction of electronic waste from obsolete it equipment

All these initiatives allow:

1. The reduction of energy consumption to operate ICT business and therefore prevent pollution caused by the production of this otherwise necessary energy. 
2. The development of the sorting and recycling of ICT business and therefore to prevent pollution by ICT production and mining resources are exhausted.

3. Changes in the habits of work with ICT by replacing physical transport telecommunication and therefore prevent pollution caused by transport and travel.

Companies that voluntarily start one or several initiatives are committed on a path of accountability towards society and the environment. Jevons paradox (Jevons, 1865) sets out that technological improvements increase the efficiency with which a resource is used, but the total consumption of that resource can increase rather than decrease. Therefore any substitution or optimization by ICTs might be compensated by quantitative increase which prevents to achieve sustainable development.

The following section presents some keys to identify positive and negative externalities.

\subsection{Identification of Positive and Negative Externalities: Practical Tips}

If today the priority is the achievement of the goals of the Millennium Development Goals (MDGs) for 2015 deadline; companies can use this list as an operational framework to analyze their contribution to SD.

First, to make products and services that are consistent with the MDGs, companies must establish consistent economic objectives with the goals of society (the Millennium goals for development). To do so, companies must first identify the priorities for improving the sustainability of their products and services, based on emerging trends and the actions of competitors. Then companies must develop these options for possible improvements, including a plan of action for these improvements and a system of continuous measurements of the new sustainable performance. A critical element of this layout consistency is the identification of the value drivers and their potential. These generators can be diverse and varied as customer satisfaction, customer loyalty, leadership, superior value brand, innovative product or service, expansion of business opportunities or improving cost structure.

In this first part, we insisted on initiatives to reduce the environmental and social negative impact of ICT in their lifecycle. Development of ICTs, and the IS, more generally contributes to the formation of new constraints for businesses. In effect also, offered communication opportunities are constraints in the sense that as competitor it is important to communicate.

\section{Act to Communicate: To New Constraints}

The development of ICTs probably generates as many constraints as new opportunities. It is now easier to communicate to the general public on how to conduct business and its commitments in terms of CSR; the development of this new type of communication gives rise to an additional differentiation factor. Communication on commitments in terms of CSR is therefore not only linked to new obligations established by law (including the 2001 France NRE Law) and to new standards of communication resulting from the practices of competitors. 


\subsection{Risks and Opportunities Generated by ICT in Terms of Communication}

Access to information that extends the development of ICT and the IS is originally linked to new demands from society. The relative loss of control of Governments in the development of world trade and the weakening trade unions as regulatory instruments are often presented being responsible for abuses concerning the working conditions of workers. In this context, the international dimension and the flexibility of nongovernmental organizations (NGOs) contribute to the development of these last effective ramparts against mentioned social problems.

It is therefore now possible to report on recent developments in the area of governance underlining on the one hand strengthening expectations of shareholders and other societal pressures emerging with the NGOs.

Carrol (1970) defines three major dimensions of the overall performance : compliance with legal and economic responsibilities, the adoption of an ethical behavior with respect to commercial and financial partners and finally the development of philanthropic actions (support to associations for example). Today, it is generally accepted that the overall performance incorporates three major dimensions: economic, social and environmental. This recognition is indeed valid in the academic world (Capron and Quairel, 2004) [2] as well as among practitioners (triple bottom line in force for many years at Danone, pioneer in this area, for example).

\subsection{The Strengthening of the Societal Requirements: Focus on the Problem of Traceability}

Among the new societal demands, those concerning the problem of traceability seem very important. We are back in the lines that follow on the origins of expectations regarding traceability to submit the answers provided by ICT.

\subsubsection{The Origins of Expectations Concerning Traceability}

Among the various requirements emanating from society, traceability deserves special attention. The new traceability requirements relate to information on the chain of production and distribution of a product. Initially, these new requirements appeared in the sector of health due to awareness of potential problems arising from dangerous products (contaminated blood). Very quickly, the food industry, due to various health problems (BSE, dioxin, chicken...), has taken the relay, making this requirement shared by consumers. Today, traceability requirements are essential to measure the social content of the latter. Textile is an interesting example of integration of social content products in the requirements of consumers in terms of traceability.

Today, three large objects of traceability are retained: (probably the oldest object tracking) people, things and processes identify three key issues associated with traceability:

- safety (especially in the agri-food sector),

- counterfeiting (primarily in the manufacturing sector),

- customer relationship (to meet the demand of information by clients). 


\subsubsection{The Answers Provided by Businesses Thanks to the SI}

Recently, traceability has benefited from progress related to computing and miniaturization:

- bar codes allow identification of products as electronic chips information storage capacity increase;

- radio-labels allow product tracking

- Finally, the capacity of databases allows following a growing list of references.

Development of security and authentication technologies therefore provides answers to questions related to the three major current issues in terms of traceability.

However, any other issue emerges with the dissemination of these technologies, because they can provide the right to respect for privacy, which is protected by articles 9 of the civil code and 8 of the European Convention of human rights violations. E.g. radiolabels embedded in objects can enable geo locate individuals against their willingness.

\section{Use the SI as SD Media}

Information systems can also be used as genuine media of sustainable development. It is this proactive use of the IS vision that we propose to explain and illustrate in this part. First, we will discuss the role of IS as a media of environmental policies, and then as a support for social policies.

\subsection{Environmental Policies Media SI}

The geographic information systems (GIS) are computer tools aimed at organizing and presenting spatially referenced alphanumeric data, and at producing plans and maps. If their application domains are quite important (especially in marketing to customers, or urban planning for the land, and even locate biology and study of the movement of animal populations...), they can contribute to a better management of natural resources. Applications of GIS contributing to the implementation of sustainable development policies open new perspectives in water resources management or implementation of monitoring stations to avoid forest fires (used by the National Office for the environment of Madagascar).

\subsection{The Media of Social Policies IS}

At a time when information and knowledge are the new levers for value creation, information systems must play an important role in certain regions disenclose. It is what explains Mamadou Decroix Diop, Minister of information, communication and promotion of technology information (note the title of this Department) of Senegal: "we missed the first two revolutions of the modern era: the agricultural and the industrial." "Africa cannot be in rest in the information society".

In addition to the necessary efforts of developing countries, the responsibility of the developed countries is to participate in these efforts. SIST (System of scientific information and technical) project seems a good illustrative approach. It is a project of 
Client companies therefore have an important role to play in the development of their suppliers. More generally, it is possible to distinguish three types of learning's from inter-organizational relations for suppliers in developing countries:

- Learning the trade, or the acquisition of new skills (we refer here to the famous "learning by doing");

- Organizational learning, linked to a new (and better) management structure and the organization itself (this is especially true when organizational asymmetry between customer and supplier is important, supplier then tends to adopt certain principles of functioning of its client);

- Learning relational behavior that allows the supplier to develop a genuine "customer orientation".

Of course, these different learning's can only emerge if the customer-supplier relationship is sufficiently stable, future-proof, that does not always favor the use of the IS.

\subsubsection{The IS at the Origins of the Weakening of Inter-organizational Relations Managers?}

By enabling the development of new relations very quickly, the inter-organizational IS contributes to increasing instability of customer-supplier relations. While sharing culture and shared values played an important role in the strengthening of relationships there are still a few years (these could be described as "claniques"), the distance requires radically different management modes. "Management by the senses", it remove by the "management by numbers" (Torres, 2004) [10] that allow the new IS.

In this context, the fragility of relations and the formalism of the latter contribute to reduce the possibilities of transfer to suppliers (among three types of learning's mentioned in the preceding point, essential elements pass through a completely informal).

\subsubsection{The Open-Book: When the SI Contribute to the Development of Suppliers} Accounting in open-book, sometimes regarded as a form of control of suppliers, is much more than that. It consists for business partners to share information related to the cost of products or components sold. This method of operation comes from Japan. Transmission of such information by suppliers to their customers in strategic nature is a widespread practice. The objective of this practice is to build trust between trading partners and facilitate the negotiation. A benefit may come for both firms in savings due to reflection joint costs if this reflection develops effectively. Another form of income is the result of the fact that, by giving access to their accounts, suppliers certify their good faith and the price they offer is less prone to attack. In this sense, the formalism introduced the development of the open-book in customer-supplier relations is likely to strengthen mutual trust. However it should be kept in mind that perverse effects can arise when the information provided is used as simple arguments negotiation assistance.

Nevertheless, the inter-organizational IS undoubtedly has an essential role to play in the development of these practices to strengthen the partnership and joint progress. 


\section{References}

1. Boudreau, M.-C., Chen, A., Huber, M.: Green IS: Building Sustainable Business Practices. In: Watson, R.T. (ed.) Information Systems: A Global Text (2008),

http://globaltext.terry.uga.edu/node/21

2. Capron, M., Quairel, F.: Myths and Realities of Responsible Business. Paris, La Découverte edn. (2004)

3. Fabbe-Costes, N.: Transformative Role of SIC and ICTs on the Distribution and Logistics. In: Fabbe-Costes, N., Colin, J., Paché, G., Vuibert, R. (eds.) Doing Research in Logistics and Distribution, Multi-Stakeholder Interfaces, pp. 171-194 (2000)

4. Kuhndt, M., Likinc, B., Stöcker, T.: Indetifying Value Drivers for Sustainable Business Development. Wuppertal Institute, Wuppertal (in preparation)

5. ORSE: How to Develop a Summary of Sustainable Development, Meetings of Working Group ORSE-EPA 2002, p. 34 (2003)

6. Viruega, A., Pellaton, J.-L.: Use of Traceability for Safety: Analysis by the Theory of Translation. In: 1st day of Research Relations between Industry and Grande Distribution Food, Avignon, March 29 (2007)

7. Fishmonger, H.: Client Relational Dynamics - Provider and Learning Opportunities: An Analysis of the Situation Suppliers French Distributors Clothing. In: CIFEPME (Congrès International Francophone in entrepreneurship and small business), Montpellier (October 2004)

8. Quairel, F., Auberger, M.: Newfoundland. Responsible for Management and Small Business: A Review of the Concept of "Corporate Social Responsibility". La Revue des Sciences de Gestion, Direction and Management 211-212, 111-126 (2005)

9. Salge, F.: The Sharing of Geographic Information for Sustainable Development, Seminar Sustainable Development, Clermont-Ferrand, pp. 24-25 (September 2008), http://www.agroparistech.fr/Colloque/ dd_ingenierie_territoriale/IMG/PDF/Atelier10.PDF

10. Torres, O.: Theorization of SME Management Test: Globalisation in the Proxémie Authorization at Leading Research in Management Sciences, University of Caen Basse (December 2004) 